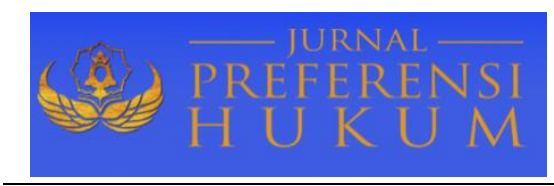

Jurnal Preferensi Hukum | ISSN: XXXX | E-ISSN: XXXX

Vol. 1, No. 2-September 2020, Hal. 88-92| Available Online at https://www.ejournal.warmadewa.ac.id/index.php/juprehum

DOI: http://doi.org/10.22225/jph.v1i2.2381.88-92

\title{
PENEGAKAN HUKUM PIDANA INTERNASIONAL DALAM KEJAHATAN PERANG TERHADAP KEMANUSIAAN
}

\author{
Fadil Muhammad, Luh Putu Sudini, I Nyoman Sujana \\ Fakultas Hukum Universitas Warmadewa, Denpasar-Bali, Indonesia
}

\begin{abstract}
Abstrak
Perang adalah kondisi di mana salah satu pihak menundukkan lawannya untuk memenuhi keinginannya, suatu tindakan fisik atau non fisik antara dua atau lebih kelompok manusia bertujuan untuk menguasai. Rumusan masalah penelitian ini adalah bagaimana peran Hukum Pidana Internasional dalam penegakkan hukum dalam kejahatan perang terhadap kemanusiaan dan bagaimana tanggungjawab negara dalam kejahatan perang terhadap kemanusiaan dalam Hukum Pidana Internasional. Metode penelitian ini menggunakan jenis penelitian hukum normatif dengan melakukan asesmen berdasarkan bahan hukum dari literatur dan merupakan proses untuk menemukan rule of law, asas hukum, dan doktrin hukum untuk menjawab permasalahan hukum yang dihadapi. Kejahatan perang dan kejahatan terhadap kemanusiaan adalah dua jenis kejahatan internasional yang ada dalam dua puluh jenis kejahatan internasional yang dirancang oleh ILC (International Law Commission) untuk merancang pembentukan pengadilan pidana internasional. Kesimpulan dari penelitian ini adalah peran Hukum Pidana Internasional dalam kejahatan perang terhadap kemanusiaan dapat disimpulkan bahwa yang terkandung dalam konvensi-konvensi yang terdapat dalam Hukum Humaniter Internasional hanya memuat perintah atau larangan saja tetapi hukum pidana internasional berperan dalam memberikan sanksi pidana terhadap pelanggaran.
\end{abstract}

Kata Kunci: Penegakkan hukum; Kejahatan internasional; Penjahat Perang; Kemanusiaan

\begin{abstract}
War is a condition in which one party subdues his opponent to fulfill his wish, a physical or non-physical act between two or more groups of people aimed at dominating. The formulation of this research problem is how the role of International Criminal Law in law enforcement in war crimes against humanity and how the state is responsible for war crimes against humanity in International Criminal Law. This research method uses a type of normative legal research by conducting an assessment based on legal material from the literature and is a process to find the rule of law, legal principles, and legal doctrine to answer legal problems faced. War crimes and crimes against humanity are two types of international crimes that exist in the twenty types of international crimes designed by the ILC (International Law Commission) to design the establishment of an international criminal tribunal. The conclusion of this research is that the role of International Criminal Law in war crimes against humanity can be concluded that the conventions contained in International Humanitarian Law only contain orders or prohibitions, but international criminal law plays a role in providing criminal sanctions for violations.
\end{abstract}

Keywords: Law enforcement; International crimes; War Criminal; Humanity

\section{PENDAHULUAN}

Tindak pidana Internasional atau International Crime sudah membawa dampak yang lebih luas, tidak hanya sekedar perubahan substansi, melainkan menyangkut masalah siapa yang dapat dimintai pertanggungjawaban dalam hal terjadinya International Crime tersebut. Apalagi pelakunya tidak hanya orang perorangan atau kelompok melainkan sebuah negara merdeka dan berdaulat (seperti dalam kasus terjadinya gerakan terorisme internasional). Cassese (2005) berpendapat bahwa Hukum Pidana Internasional adalah sekumpulan aturan Hukum Internasional yang melarang kejahatankejahatan internasional dan membebankan kewajiban kepada negara-negara untuk menuntut dan menghukum sekurang-kurangnya beberapa bagian dari kejahatan-kejahatan itu. Di dalamnya juga mengatur prosedur untuk menuntut dan mengadili orang-orang yang dituduh melakukan 
kejahatan itu. Tindak pidana internasional yang lahir dari sejarah perkembangan konvensi mengenai hak asasi manusia merupakan konsekuensi logis akibat Perang Dunia II yang meliputi bukan hanya korban-korban perang mereka yang termasuk combatant, melainkan juga korban penduduk sipil (noncombatant) yang harusnya dilindung dalam suatu perperangan. Salah satu dari tindak pidana internasional ini ialah crime of genocide atau kejahatan genosida sesuai dengan deklasrasi PBB tanggal 11 Desember 1946 yang menetapkan genosida sebagai kejahatan menurut hukum internasional. Yang menjadi inti dari pembahasan pada menulisan ini adalah jenis tindak pidana internasional kejahatan perang (war crime) dan kejahatan terhadap kemanusiaan (crime against humanity) yang disimpulkan menjadi kejahatanperang terhadap kemanusiaan karena keduanya saling berkaitan dan kejahatan perang juga melanggar nilai-nilai kemanusiaan dan tentunya hukum pidana internasional mempunya aturan yang mengatur terhadap dua jenis tindak pidana internasional itu.

Kejahatan perang merupakan perbuatan-perbuatan yang dikategorikan sebagai pelanggaran berat (grave breaches) terhadap Konvensi Jenewa I, II, III, IV dan Protokol Tambahan I. Dapat disebutkan antara lain yaitu perbaikan keadaan anggota angkatan bersenjata yang terluka dan sakit di darat (amelioration of the condition of the wounded and sick in armed forces in the field), perbaikan keadaan anggota angkatan bersenjata yang terluka, sakit, dan karam di laut (amelioration of the condition of wounded, sick, and shipwrecked members of armed forces at sea), perlakuan tawanan perang (Protection of civilian persons in time of war), perlindunganorang sipil pada masa perang (Protection of civilian persons in time of war), dan Protokol Tambahan I yaitu memuat elaborasi ketentuan-ketentuan perlindungan terhadap korban konflik bersenjata internasional.

Istilah kejahatan perang berarti kuas dan mencakuo banyak perbuatan tertentu, seperti penyiksaan (penganiayaan), termasuk penggunaan narkotika untuk mengubah pikiran atau prosedur medis tak waras, mutilasi fisik, eksperimen medis, atau peralkuan tidak manusiawi, dan lain-lain. Kejahatan terhadap kemanusiaan termasuk terasuk baru, yang berhubungan dengan doktirin tentang perlindungan HAM, yang dapat dilakukan pada masa perang maupun damai. Dasar hukum bagi kejahatan ini adalah Konvensi Den Haag Ke IV tahun 1907, yang menyatakan bahwa penduduk sipil dan pihak-pihak berperang akan tetap tunduk pada perlindungan dan prinsip-prinsip hukum Internasional, yang ditetapkan dala kebiasaan bangsa-bangsa beradab. Doktrin perlindugan terhadap kemanusiaan yang dikenal dengan The Marten Clause ini dijadikan dasar perlindungan terhadap korban dalam konflik bersenjata internasional seperti ditetapkan dalam Protokol Tambahan I Tahun 1977.

Sebagaimana halnya dengan agresi, kejahatan terhadap kemanusiaan juga merupakan yurisdiksi Pengadilan Pidana Internasional. Bentuk-bentuk perbuatan yang termasuk kejahatan ini diatur secara rinci dalam Pasal 7 Statuta Roma yaitu oembunuhan (murder), pemusnahan (extermination), perbudakan (enslavement), deportasi atau pemindahan paksa populasi (deportation or focible transfer of population), pemenjaraan atau perampasan kebebasan fisik lainnya yang melanggar peraturan dasar hukum internasional (Imprisonment or other severe deprivation of physical liberty in violation of fundamental rules of international law), penyiksaan (torture), penganiayan terhadap kelompok atau kolektivitas apapun yang dapat dikenali berdasarkan alasan politik, ras, nasional, etnis, nudaya, agama, gender, atau lainnya yang diakui secara universal, yang tidak dapat dipungkiri di bawah hukum internasional, sehubungan dengan tindakan yang diatur dalam ayait ini atau kejahatan apa pun di dalam yurisdiksi pengadilan (persecution against any identifiable group or collectivity on political, racial, national, ethnic, cultural, religious, gender, or other grounds that are universally recognized, as impermissible under international law, in connection with any act referred to in this paragraph any crime within the jurisdiction of the court).

Penelitian terdahulu juga telah disampaikan oleh (Wardana \& Adiastuti, 2019) menyimpulkan bahwa penyelesaian terhadap pelanggaran berat HAM secara hukum pada dasarnya mengacu kepada prinsip exhaustion of local remedies melalui mekanisme forum pengadilan nasional. kejahatan terhadap kemanusiaan, kejahatan perang dan kejahatan agresi sesuai dengan Rome Statute Pasal 5 ayat (1). Siapapun orang yang melakukan kejahatan akan dihukum secara individu sesuai dengan Rome Statute Pasal 25 ayat (2) dan diadili tanpa adanya perbedaan mengenai Kapasitas atau Jabatannya sesuai dengan Pasal 27. Adapun tujuan penelitian ini untuk mengetahui bagaimana peran Hukum Pidana Internasional dalam penegakkan hukum dalam kejahatan perang terhadap kemanusiaan dan mengetahui bagaimana tanggungjawab negara dalam kejahatan perang terhadap kemanusiaan dalam Hukum Pidana Internasional. 


\section{METODE PENELITIAN}

Berdasarkan permasalahan yang dirumuskan, tipe penelitian ini menggunakan jenis penelitian hukum normatif yaitu dengan melakukan pengkajiannya berdasarkan bahan-bahan hukum dari literatur dan merupakan suatu proses untuk menemukan aturan hukum, prinsip-prinsip hukum, maupun doktrin-doktrin hukum guna menjawab isu hukum yang dihadapi. Dan juga ketetapan hukum dalam menegakkan hukum pidana internasional terhadap kejahatan perang dan kejahatan terhadap kemanusiaan. Pendekatan masalah yang digunakan adalah perundang-undangan yaitu dengan menelaah peraturan perundang-undangan yaitu dengan menelaah peraturan perundang-perundangan yang berhubungan dengan permasalahan, pendekatan konseptual yaitu pendekatan melalui pandangan - pandangan dan doktrin-doktrin yang berkembang di dalam ilmu hukum, danpendekatan kasus dilakukan dengan melakukan telaah pada kasus-kasus yang berkaitan dengan isu hukum yang dihadapi.

\section{HASIL DAN PEMBAHASAN}

\section{Unsur-Unsur Hukum dalam Pengaturan Pidana Internasional}

Unsur-unsur hukum pengaturan pidana internasional menurut (Atmasasmita, 2000) mengatakan bahwa ada satu unsur pokok yang membedakan suatu perbuatan sebagai tindak pidana internasional atau bukan, yaitu bahwa tindakan tersebut harus mengandung unsur transnasional atau internasional yang salah satunya adalah lintas batas teritorial (transboundaries). Di samping juga unsur kebutuhan akan kerjasama antar negara (necessity element). (Bassiouni, 1986) telah menggambarkan ketiga unsur hukum tindak pidana internasional itu secara lebih rinci. Unsur internasional: yang termasuk di dalamnya adalah: 1) Direct threat to World Peace and Security (Ancaman langsung terhadap Perdamaian dan Keamanan Dunia); 2) Indirect threat to World Peace and Security (Ancaman tidak langsung terhadap perdamaian dan kemanan dunia); 3) "Shocking" to the conscience of humanity ("Mengejutkan" hati nurani umat manusia). Unsur transnasional yang termasuk ke dalamnya adalah: 1) Conduct affecting more than one state (Perilaku yang mempengaruhi lebih dari satu negara); 2) Conduct including or affecting citizens of more than one state (melakukan termasuk atau mempengaruhi warga negara dari kebih dari satu negara bagian); 3) Means and methods transcend national boundaries (Sarana dan metode melampaui batas nasional). Unsur necessity (kebutuhan) adalah cooperation of States necessary to enforce (kerjasama Negara yang diperlukan untuk menegakkan).

\section{Peran Hukum Pidana Internasional dalam Kejahatan Perang terhadap Kemanusiaan}

Peran Hukum Pidana Internasional dalam kejahatan perang terhadap kemanusiaan secara sederhana dapat dilihat dari sekumpulan norma-norma yang mengatur perihal peran. Secara substansial, normanorma yang mengatur perihal perang itu bisa dibedakan menjadi dua kategori, yaitu norma-norma yang mengatur tentang kapan dan dalam keadaan bagaimana sebuah perang yang sah dapat dilancarkan (ius ad bellum), serta norma-norma yang mengatur hak dan kewajiban dari pihak-pihak yang terlibat dalam perang (ius in bello) (Denny Ramdany, Heribertus Jaka Triyana, Sefriani, 2015).

Peran Hukum Pidana Internasional dalam kejahatan perang terhadap kemanusiaan juga dapat dilihat dari hubungan Hukum Pidana Internasional dengan Hukum Humaniter Internasional (Hukum Perang), yaitu pada konvensi-konvensi yang ada pada Hukum Humaniter Internasional hanya sekedar menampilkan perintah atau larangan saja dan sama sekali tidak mengatur tentang sanksi pidana terhadap pelanggaran perintah atau larangan itu (Ambarwati, Denny Ramadhany, 2010). Dengan kata lain, rumusan norma dalam konvensi-konvensi itu.

Dalam kejahatan terhadap kemanusiaan peran hukum pidana internasional dapat dilihat dari dasar hukum bagi kejahatan ini yaitu Konvensi Den Haag ke IV tahun 1907, yang menyatakan bahwa penduduk sipil dan pihak-pihak berperang akan tetap tunduk pada perlindungan dan pada prinsipprinsip pokok hukum internasional, yang ditetapkan dalam kebiasaan bangsa-bangsa beradab.

\section{Kejahatan Perang dan Dasar Hukum Tanggung Jawab Negara}

Secara sederhana, "kejahatan perang" berpangkal dari tindakan yang melanggar hukum dan kebiasaan dalam konflik bersenjata. Namun, umumnya dipahami bahwa tidak setiap pelanggaran terhadap norma hukum dan kebiasaan dalam konflik bersenjata dapat dikategorikan sebagai kejahatan perang. 
Salah satu pandangan ini antara lain tercermin dari pendapat (Cryer, 2007), yang mengatakan bahwa "war crimes law deals with the criminal responsibility of individuals for serious violations of international humanitarian law." (hukum kejahatan perang berurusan dengan tanggung jawab pidana individu untuk pelanggaran berat hukum humaniter internasional). Kejahatan perang adalah sengaja melakukan perbuatan-perbuatan yang dikategorikan sebagai pelanggaran berat (grave breaches) terhadap Konvensi Jenewa I, II, III, IV, dan protokol tambahan I, bila perbuatan tersebut berakibat kematian, penderitaan berat, atau luka serius pada orang-orang yang dilindungi, tawanan perang, atau pun penduduk sipil. Istilah kejahatan perang berarti luas dan mencakup banyak perbuatan tertentu, seperti penyiksaan (penganiayaan), termasuk penggunaan narkotika untuk mengubah pikiran atau prosedur medis tak waras, mutilasi fisik, eksperimen medis, atau perlakuan tidak manusiawi, dan lainlain.

Dasar hukum tanggung jawab negara dalam Hukum Pidana Internasional yang berupa kewajiban untuk menuntut pelaku tindak pidana internasional ditemui dalam berbagai instrumen hukum internasional (Adolf, 2008). Di antara instrumen hukum internasional yang mengatur kewajiban negara untuk menuntut pelaku sebagai berikut: 1) Konvensi tentang pencegahan dan penghukuman atas kejahatan genosida tahun 1948; 2) Convention on the Non-applicability of Statutory Limitations to War Crimes and Crimes against Humanity, tahun 1968. (Konvensi tentang Keterbatasan Keterbatasan Ketertiban terhadap Kejahatan Perang dan Kejahatan terhadap Kemanusiaan); 3) Konvensi Jenewa 1949; 4) Protokol Tambahan I tahun 1997; 5) Statuta Mahkamah Internasional Ad Hoc Den Haag dan Rwanda; 6) Statuta Roma.

\section{Unsur-Unsur Kejahatan Perang dan Bentuk Tanggung Jawab Negara dalam Penegakkan Hukum Pidana Internasional}

Mengenai unsur- unsur kejahatan perang berdasarkan ketentuan pasal 8, ayat (2) (c) dan (e), tunduk pada ketentuan pembatasan yang ditetapkan dalam pasal 8, ayat (2) (d) dan (f) yang bukan merupakan unsur kejahatan. Unsur-unsur kejahatan perang di bawah pasal 8, ayat (2), dari Statuta Roma harus ditafsirkan dengan memperhatikan kerangka kerja yang telah dikembangkan dalam hukum internasional tentang konflik bersenjata yang mencakupi, sebagaimana mestinya, hukum internasional tentang konflik bersenjata yang dapat diterapkan dalam konflik bersenjata di laut.

Bentuk-bentuk tanggung jawab negara ialah menurut Convention on the Non-applicability of Statutory Limitations to War Crimes and Crimes against Humanity (Konvensi Tentang KeterbatasanKeterbatasan Ketertiban Terhadap Kejahatan Perang dan Kejahatan Terhadap Kemanusiaan) tahun 1968. Menurut konvensi ini lembaga kedaluarsa tidak berlaku terhadap tindak pidana perang dan tindak pidana terhadap kemanusiaan. Dengan kata lain sampai kapanpun seorang pelaku tindak pidana tersebut akan tetap diadili. Terhadap tindak pidana ini Negara berkewajiban untuk: a) Membuat perundangan atau perjanjian untuk melaksanakan ekstradisi bagi pelaku tindak pidana ini; b) Berkewajiban berdasarkan proses-proses konstitusional, perundangan dan ketentuan hukum lainnya yang menjamin penuntutan dan pemidanaan terhadap pelaku tindak pidana ini. Sedangkan Bentuk tanggung jawab negara menurut Statuta Roma yaitu negara-negara peserta memiliki dua macam kewajiban pokok terkait dengan tindak pidana internaional yang termasuk yurisdiksi Pengadilan yaitu: 1) Negara peserta berkewajiban untuk membawa setiap pelaku tindak pidana genosida, tindak pidana terhadap kemanusiaan, tindak pidana perang, serta tindak pidana agresi ke hadapan pengadilan, dan "merupakan kewajiban setiap negara untuk melaksanakan yurisdiksinya terhadap setiap tindak pidana internasional"; 2) Negara peserta harus bekerja sama penuh dalam penegakan Hukum Pidana Internasional, terutama bila pengadilan menetapkan akan memberlakukan jurisdiksinya sesuai dengan asas pelengkap tadi. Pasal 86 Statuta menyatakan antara lain: "bekerjasama penuh dengan Pengadilan Pidana Internasional dalam proses penyidikan dan penuntutan sesuai dengan jurisdiksinya yang dimiliki oleh Pengadilan Pidana Internasional”.

\section{SIMPULAN DAN SARAN}

\section{Simpulan}

Peran Hukum Pidana Internasional dalam kejahatan perang terhadap kemanusiaan dapat disimpulkan yaitu tertera pada konvensi-konvensi yang ada pada hukum humaniter internasional hanya memuat perintah atau larangan saja namun hukum pidana internasional berperan dalam memberikan sanksi 
pidana terhadap pelanggaran perintah atau larangan itu. Berikutnya tanggung jawab negara dalam Hukum Pidana Internasional yang berupa kewajiban untuk menuntut pelaku tindak pidana intenasional ditemui dalam berbagai instrumen hukum internasional. Berdasarkan Konvensi Tentang Keterbatasan-Keterbatasan Ketertiban Terhadap Kejahatan Perang dan Kejahatan Terhadap Kemanusiaan tahun 1968, tindak pidana perang dan tindak pidana terhadap kemanusiaan sampai kapanpun seorang pelaku tindak pidana tersebut akan tetap diadili dan tidak mengenal kedaluarsa. Negara tetap berkewajiban untuk melaksanakan ekstradisi bagi pelaku dan berkewajiban untuk menjamin penuntutan dan pemidanaan terhadap pelaku tindak pidana ini. Bentuk tanggung jawab negara menurut Statuta Roma yaitu negara-negara peserta memiliki dua macam kewajiban pokok yaitu negara peserta harus membawa setiap pelaku tindak pidana genosida, tindak pidana terhadap kemanusiaan, tindak pidana perang serta tindak pidana agresi ke hadapan pengadilan dan negara peserta harus bekerja sama penuh dalam penegakan Hukum Pidana Internasional, terutama bila pengadilan menetapkan akan memberlakukan jurisdiksinya sesuai dengan asas pelengkap tadi.

\section{Saran}

Peran Hukum Pidana Internasional dalam Kejahatan Perang terhadap kemanusiaan sudah mengatur mengenai penegakan dalam pelangaran Konvensi Jenewa tentang perlindungan penduduk sipil, namun dalam praktik ada kalanya negara peserta enggan mengadili atau mengadili secara tidak adil para pelaku, terlebih-lebih terhadap mereka yang melakukan pelanggaran berat terhadap ketentuan Konvensi Jenewa itu. Saran dari penulis adalah agar negara-negara peserta Konvensi Jenewa membuat aturan yang lebih tegas terhadap negara peserta yang enggan mengadili atau mengadili secara tidak adil para pelaku. Saran dari penulis seharusnya negara-negara peserta konvensi memperbarui aturan-aturan yang ada pada Konvensi Jenewa dan Statuta Roma karena penulis menilai hukuman bagi pelaku tindak pidana kejahatan perang sangat minim dan tidak adil dan tidak memberikan kewajiban ganti rugi terhadap pihak korban, hukuman tersebut dinilai tidak sesuai terhadap kejahatan perang yang sudah dilakukan oleh pelaku.

\section{DAFTAR PUSTAKA}

Adolf, H. (2008). Buku Hukum Internasional instrumen hukum tentang kontrak internasional. Refika Aditama.

Ambarwati, Denny Ramadhany, R. R. (2010). Hukum Humaniter. Rajawali Press.

Atmasasmita, R. (2000). Pengantar Hukum Pidana Internasional, Cetakan Kedua. PT Refika Aditama.

Bassiouni, M. C. (1986). International Criminal Law, Vol 1, Crimes. Transnational Publisher.

Cassese, A. (2005). International Law.

Cryer, R. (2007). An Introduction to International Law and Procedure. Cambridge University Press.

Denny Ramdany, Heribertus Jaka Triyana, Sefriani, Y. T. N. D. (2015). Konteks dan Perspektif Politik Terkait Hukum Humaniter Internasional Kontemporer. Rajawali Press.

Wardana, A. K., \& Adiastuti, A. (2019). Pertanggungjawaban Negara Atas Kejahatan Kemanusiaan Terhadap Etnis Rohingya di Myanmar Antara Kurun Waktu Tahun 2017-2018. 5(2). 